\title{
Design Analysis of Driven Pile Foundations of Retaining Walls in Granular Soils
}

\author{
Muhammad Suradi ${ }^{1, a}$, Abdul Nabi ${ }^{1, b}$, Haeril Abdi Hasanuddin ${ }^{1, c}$, \\ Andi Muhammad Muktadiru ${ }^{1, d}$, Agung Ridhatullah ${ }^{1, e}$, \\ ${ }^{1}$ Civil Engineering Department, Ujung Pandang State Polytechnic, Jl. P. Kemerdekaan Km 10, Makassar, 90245, Indonesia \\ a msuradi@poliupg.ac.id; ${ }^{\mathrm{b}}$ abd.nabis@gmail.com; ${ }^{\mathrm{c}}$ irhiel@yahoo.com; ${ }^{\mathrm{d}}$ uttafull@gmail.com; ${ }^{\mathrm{e}}$ agung.ridhatullah@gmail.com
}

\begin{abstract}
The aim of this paper is to investigate the effect of the pile of retaining wall design parameters including slope height and soil shear strength on the depth of driven piles. Parametric study was performed by varying the slope height and internal friction angle of granular soils in order to investigate the effect of these parameters on the pile depth. This study indicated that the pile depth increased more significantly with the increase of slope height for low internal friction angle $\left(7,69 \mathrm{~m}\right.$ for $\left.\phi=20^{\circ}\right)$ than those for high internal friction angle $\left(3,87 \mathrm{~m}\right.$ for $\left.\phi=40^{\circ}\right)$ with the increase of slope height from $2 \mathrm{~m}$ to $10 \mathrm{~m}$. Meanwhile this study showed larger increase of the pile depth $(2.86 \mathrm{~m})$ for the dcrease in internal friction angle when slope soils and subgrade have the same internal friction angle than those when they have different internal friction angle $(1.41 \mathrm{~m})$ for $6 \mathrm{~m}$ in the slope height with the decrease of internal friction angle of soils from $\phi=40^{\circ}$ to $20^{\circ}$.
\end{abstract}

Keywords- driven piles; retaining walls; pile depth; slope height; internal friction angle

\section{Introduction}

Pile foundations are usually designed to retain vertical and lateral loads. However, the pile in particular circumstances only takes account of lateral loads when it is designed for retaining walls constructed to retain landfill or cut slopes. For this purpose, instead of sheet piles, geogrid reinforcement and others, driven piles may be a realistic alternative because the pile material is easily obtained and installed in any types of soil. Therefore, this pile foundation is specifically designed to retain lateral loads.

The pile foundation must be safe from lateral resistance and displacement as well as material failure. Design mechanism of this pile is different from a common mechanism pile design which mainly considers vertical loads in design analysis. This pile is particularly useful when it is applied in granular soils which are vulnerable to slope failures. This study aimed to investigate the effect of slope height and internal friction angle of soil on the depth of driven piles.
Factors affecting shear strength of granular soils are different from those of cohesive soils. The shear strength of granular soils is characterized by gradation, grain shape and compaction while that of cohesive soils is characterized by plasticity, mineral content and consolidation. Granular soils tend to have high shear strength indicated by its internal friction angle when they are well-graded, angular grain and dense package as listed in Table 1. The internal friction angle positively correlates to lateral pressures of soils.

Table 1. Internal friction angle of soil types [1]

\begin{tabular}{|c|c|c|}
\hline No. & Types of soil & $\begin{array}{c}\text { Inernal friction } \\
\text { angle, } \phi\left(^{\circ}\right)\end{array}$ \\
\hline 1. & $\begin{array}{l}\text { Pasir dengan butiran bulat: } \\
\text { - Lepas } \\
\text { - Kepadatan sedang } \\
\text { - Padat }\end{array}$ & $\begin{array}{l}27-30 \\
30-35 \\
35-38\end{array}$ \\
\hline 2. & $\begin{array}{l}\text { Pasir dengan butiran tajam: } \\
\text { - Lepas } \\
\text { - Kepadatan sedang } \\
\text { - Padat }\end{array}$ & $\begin{array}{l}30-35 \\
35-40 \\
40-45\end{array}$ \\
\hline 3. & Krikil bercampur pasir & $34-48$ \\
\hline 4. & Lanau & $26-35$ \\
\hline
\end{tabular}

\section{A. Lateral Pressures}

Lateral pressures generated by soils include active pressures, passive pressures and lateral pressures at rest. The lateral pressures are a function of vertical stress $[1,3,6]$ as shown in Equation (1).

$$
\sigma_{\mathrm{h}}=\mathrm{K}_{\mathrm{h}} \sigma_{\mathrm{v}}{ }^{\prime}
$$

where : $\sigma_{\mathrm{h}}=$ lateral pressures

$\sigma_{\mathrm{v}}{ }^{\prime}=$ effective vertical stresss

$\mathrm{K}_{\mathrm{h}}=$ lateral pressure coefficient

The lateral pressure coefficient at rest $\left(\mathrm{K}_{0}\right)$ is applied anywhere in soils in equilibrium. However, the coefficient becomes active or passive coefficients when lateral 
displacement of soils occures. Soils are in active condition when the displacement away from the soils whereas passive condition when the displacement towards the soils. The displacements required to generate the active and passive conditions are illustrated in Figure 1.

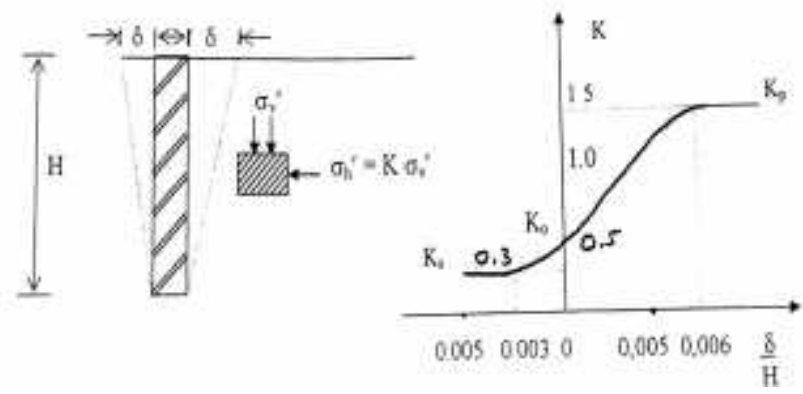

Figure 1. Lateral displacement required to generate active and passive conditions $[1,3,6]$

The lateral coefficients for pressure at rest $\left(\mathrm{K}_{0}\right)$, active pressure $\left(\mathrm{K}_{\mathrm{a}}\right)$ and passive pressure $\left(\mathrm{K}_{\mathrm{p}}\right)$ are determined using Equations (2a, 2b and 2c) $[1,3,6]$.

$$
\begin{aligned}
& \mathrm{K}_{0}=1-\sin \phi \\
& \mathrm{K}_{\mathrm{a}}=\tan ^{2}\left(45^{\circ}-\phi / 2\right) \\
& \mathrm{K}_{\mathrm{p}}=\tan ^{2}\left(45^{\circ}+\phi / 2\right)
\end{aligned}
$$

\section{B. Lateral Resistance}

The piles retaining lateral soil pressures behave as freehead piles. Lateral resistance of driven piles in granular soils is determined in 2 mechanisms, short or long piles. To define whether piles are short or long depends on ratio between the ple driving depth (L) and stiffness (T). It is a short pile when $\mathrm{L} / \mathrm{T} \leq 2$. The pile stiffness is given using Equation $(3)[4,5,7]$.

$$
T=\left(\frac{E I}{\eta_{h}}\right)^{0.2}
$$

where : $\mathrm{E}=$ modulus of elasticity of pile material $(\mathrm{kPa})$

$$
\begin{aligned}
& I=\text { moment of inertia of pile section }\left(\mathrm{m}^{4}\right) \\
& \eta_{h}=\text { modulus of subgrade reaction }\left(\mathrm{kN} / \mathrm{m}^{3}\right)
\end{aligned}
$$

When a driven pile is laterally loaded as a short pile, it behaves as shown in Figure 2.

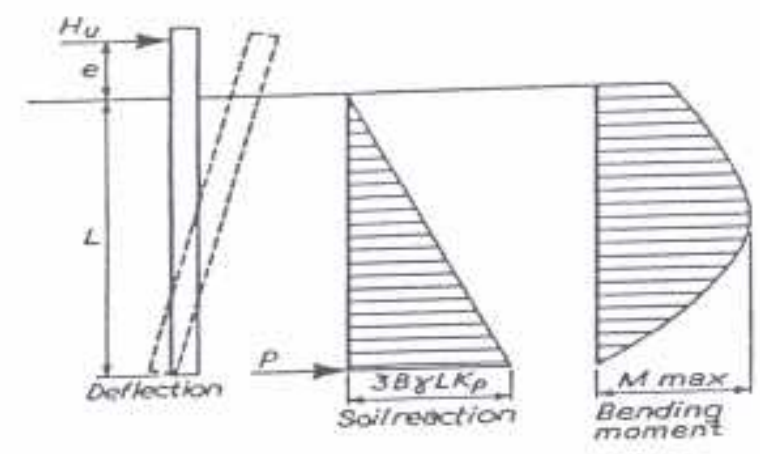

Figure 2. Diagram of subgrade reaction and bending moment for short piles $[2,5,7]$

Ultimate lateral resistance of the pile $\left(\mathrm{H}_{\mathrm{u}}\right)$ is expressed in Equation (4) [2, 5, 7].

$$
\mathrm{H}_{\mathrm{u}}=\frac{0.5 \cdot \gamma^{\prime} \cdot \mathrm{L}^{3} \cdot \mathrm{B} \cdot \mathrm{K}_{\mathrm{p}}}{(\mathrm{e}+\mathrm{L})}
$$

where: $\gamma^{\prime}=$ effective unit weight of soils

$$
\mathrm{B}=\text { diameter of pile section }
$$

Depth of maximum moment and the maximum moment are given in Equation (5) and (6) respectively [5, 7].

$$
\begin{aligned}
& x_{0}=0.82\left(\frac{H_{u}}{\gamma^{\prime} B K_{p}}\right) \\
& \mathrm{M}_{\max }=\mathrm{H}_{\mathrm{u}}\left(\mathrm{e}+1.5 \mathrm{x}_{0}\right)
\end{aligned}
$$

Correlation among the parameters in equations above is presented in curves as shown in Figure 3.

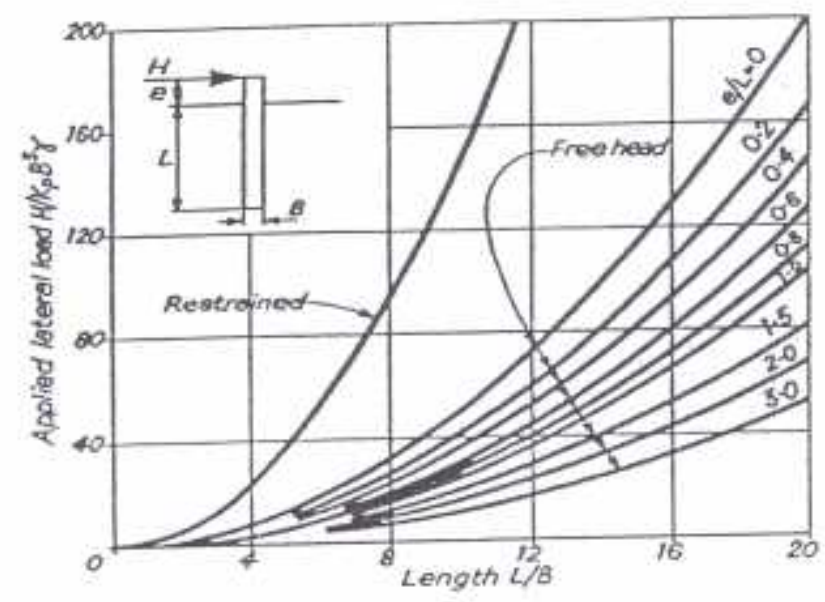

Figure 3. Curves of ultimate lateral resistance of short piles in granular soils $[5,7]$ 


\section{Research Methodology}

Parametric study was performed to investigate the effects of slope height and internal friction angles of soil on the depth of driven piles as sketched in Figure 4. These two parameters are main parameters in the pile design analyses. The slope height was varied from $2 \mathrm{~m}$ to $10 \mathrm{~m}$ while the internal friction angle of soils was varied from $20^{\circ}$ to $40^{\circ}$. When the slope height was varied, the design analysis used a fixed value of internal friction angle. On the other hand, a fixed value of the slope height was used when the internal friction angle of soils was varied. Overall scenario of this parametric study is presented in Table 2. This study assumed using a concrete pile with $35 \mathrm{~cm}$ in section diameter and $10^{7} \mathrm{kPa}$ in modulus of elasticity and cut/landfill soils with $18 \mathrm{kN} / \mathrm{m}^{3}$ volume weight and $2 \times 10^{5} \mathrm{kN} / \mathrm{m}^{3}$ in modulus of subgrade reaction.

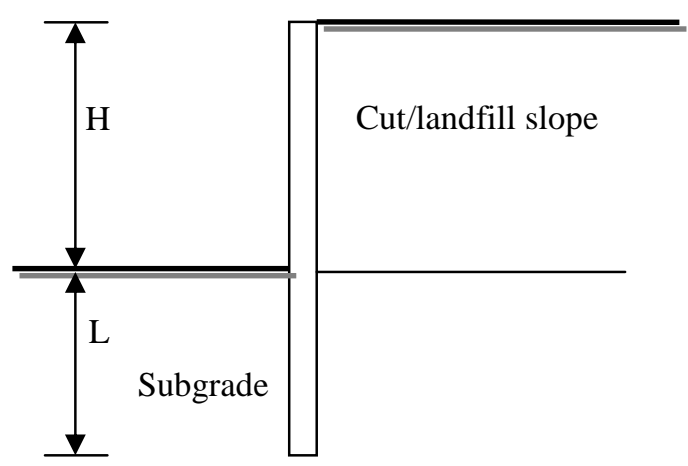

Figure 4. The case of piles retaining lateral pressure of soils

Table 2. Variable Parameters Used in the Parametric Study

\begin{tabular}{|c|c|c|}
\hline \multirow{2}{*}{ Slope Height $(\mathrm{m})$} & \multicolumn{2}{|c|}{ Internal Friction Angle, $\phi\left({ }^{\circ}\right)$} \\
\hline 2 & Slope Soils & Subgrade \\
\hline 4 & 20 & 20 \\
\hline 6 & 30 & 30 \\
\hline 8 & 40 & 40 \\
\hline 10 & 20 & 20 \\
\hline 6 & 30 & 30 \\
\cline { 2 - 3 } $\begin{array}{c}\text { Slope Soils } \\
\text { Subgrade }\end{array}$ & 40 & 40 \\
\hline $\begin{array}{c}6 \\
\text { Slope Soils } \neq \\
\text { Subgrade }\end{array}$ & 20 & 30 \\
\cline { 2 - 3 } & 30 & 20 \\
\hline $\begin{array}{c}\text { Slope Soils } \neq \\
\text { Subgrade }\end{array}$ & 40 & 30 \\
\hline
\end{tabular}

The analysis technique used the Microsoft Excel. Equations and diagram previously presented were utilized in this analysis. Two scenarios of the parametric study were applied when internal friction angle of soils was varied. First, the analysis used slope soils and subgrade with the same internal friction angle. This is quite close to cut slopes.
Second, slope soils and subgrade have different internal friction angle and it may be close to landfill slopes.

\section{Results and Discussion}

The design analysis was devided into 2 scenarios: the pile design based on variation of slope height $(\mathrm{H})$ and internal friction angle of slope soils and subgrade as presented in Table 1.

\section{A. The Effect of Slope Height on the Depth of Driven Piless}

In this scenario, the pile was designed in 3 different internal friction angles $\left(\phi=20^{\circ}, 30^{\circ}\right.$ and $\left.40^{\circ}\right)$ of slope soils and subgrade to retain slope with variation of height from $2 \mathrm{~m}$ to $10 \mathrm{~m}$. The slope soils and subgrade were assumed as homogeneous soils. The lateral pressures are function of slope heights and internal friction angles of slope soils while the lateral resistances are function of pile depth and internal friction angles of subgrade. The correlation among these parameters is expressed in the previous equations and figures. Thus, the pile depth was determined using Equation (4) and curves shown in Figure 3 and results were presented in Table $3 \mathrm{a}, 3 \mathrm{~b}$ and $3 \mathrm{c}$, and shown in Figure 5.

Table 3a. The depth of driven piles obtained from variation of the slope height with internal friction angle of slope soils and subgrade, $\phi_{\mathrm{f}}=\phi_{\mathrm{s}}=20^{\circ}$

\begin{tabular}{|c|c|c|c|c|c|c|}
\hline $\mathrm{H}$ & $\mathrm{P}_{\mathrm{a}}$ & $\mathrm{e}$ & $\mathrm{L}(\mathrm{m})$ & $\mathrm{P}_{\mathrm{a}}(\mathrm{e}+\mathrm{L})$ & $0,5 \gamma \mathrm{K}_{\mathrm{p}} \mathrm{BL}^{3}$ & Control \\
\hline 2 & 17,64 & 0,67 & 1,93 & 45,86 & 46,20 & Safe \\
\hline 4 & 70,56 & 1,33 & 3,85 & 365,50 & 366,71 & Safe \\
\hline 6 & 158,76 & 2,00 & 5,77 & 1233,56 & 1234,43 & Safe \\
\hline 8 & 282,24 & 2,67 & 7,70 & 2926,83 & 2933,68 & Safe \\
\hline 10 & 441,00 & 3,33 & 9,62 & 5710,95 & 5720,92 & Safe \\
\hline
\end{tabular}

Table 3b. The depth of driven piles obtained from variation of the slope height with internal friction angle of slope soils and subgrade, $\phi_{\mathrm{f}}=\phi_{\mathrm{s}}=30^{\circ}$

\begin{tabular}{|c|c|c|c|c|c|c|}
\hline $\mathrm{H}$ & $\mathrm{P}_{\mathrm{a}}$ & $\mathrm{e}$ & $\mathrm{L}(\mathrm{m})$ & $\mathrm{P}_{\mathrm{a}}(\mathrm{e}+\mathrm{L})$ & $0,5 \gamma \mathrm{K}_{\mathrm{p}} \mathrm{BL}^{3}$ & Control \\
\hline 2 & 11,88 & 0,67 & 1,40 & 24,59 & 25,93 & Safe \\
\hline 4 & 47,52 & 1,33 & 2,74 & 193,41 & 194,39 & Safe \\
\hline 6 & 106,92 & 2,00 & 4,11 & 653,28 & 656,08 & Safe \\
\hline 8 & 190,08 & 2,67 & 5,48 & 1549,15 & 1555,15 & Safe \\
\hline 10 & 297,00 & 3,33 & 6,84 & 3020,49 & 3024,13 & Safe \\
\hline
\end{tabular}

Table 3c. The depth of driven piles obtained from variation of the slope height with internal friction angle of slope soils and subgrade, $\phi_{\mathrm{f}}=\phi_{\mathrm{s}}=40^{\circ}$

\begin{tabular}{|c|c|c|c|c|c|c|}
\hline $\mathrm{H}$ & $\mathrm{P}_{\mathrm{a}}$ & $\mathrm{e}$ & $\mathrm{L}(\mathrm{m})$ & $\mathrm{P}_{\mathrm{a}}(\mathrm{e}+\mathrm{L})$ & $0,5 \gamma \mathrm{K}_{\mathrm{p}} \mathrm{BL}^{3}$ & Control \\
\hline 2 & 7,92 & 0,67 & 0,97 & 12,99 & 13,05 & Safe \\
\hline 4 & 31,68 & 1,33 & 1,94 & 103,59 & 104,42 & Safe \\
\hline 6 & 71,28 & 2,00 & 2,91 & 349,98 & 352,41 & Safe \\
\hline 8 & 126,72 & 2,67 & 3,87 & 828,75 & 828,89 & Safe \\
\hline 10 & 198,00 & 3,33 & 4,84 & 1617,66 & 1621,45 & Safe \\
\hline
\end{tabular}

Note: $\mathrm{H}=$ slope height, $\mathrm{P}_{\mathrm{a}}=$ active pressures of soils as lateral loads on the pile $(\mathrm{kN} / \mathrm{m}$ '), e $=$ moment arms of the lateral loads $(\mathrm{m}), \mathrm{L}=$ pile depth $(\mathrm{m})$, the pile depth is safe when $0,5 \gamma \mathrm{K}_{\mathrm{p}} \mathrm{BL}^{3}>\mathrm{P}_{\mathrm{a}}(\mathrm{e}+\mathrm{L})$ 


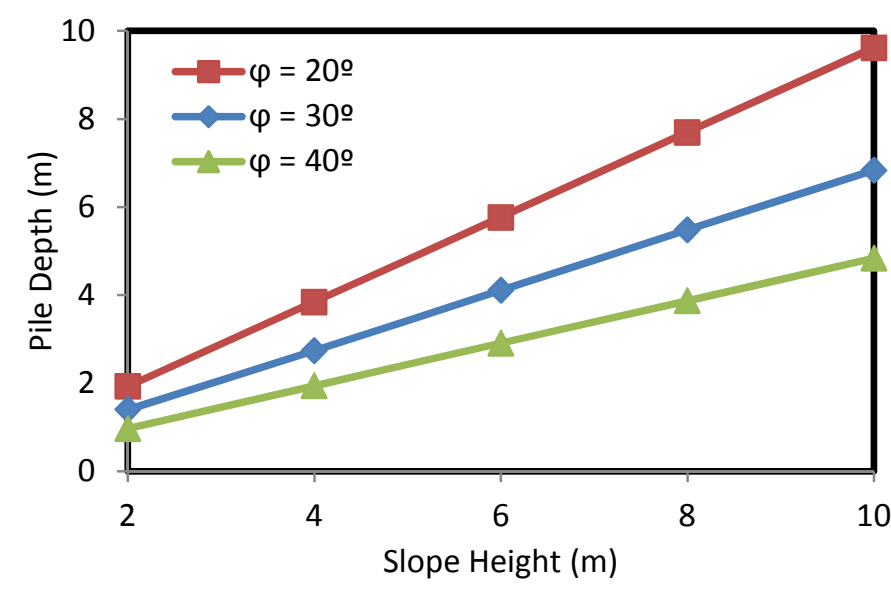

Figure 5. Slope height vs pile depth curves in 3 different internal friction angles of soils $\left(\phi=20^{\circ}, 30^{\circ}\right.$ and $\left.40^{\circ}\right)$

The results indicated that the effect of slope height on pile depth was greater in subgrade and slope soils with lower internal friction angles as shown in Figure 5. This is reasonable because slope soils with low internal friction angle give high lateral pressure on the pile whereas low subgrade resistance was resulting from the subgrade with low internal friction angle. The pile depth increased 7,69 $\mathrm{m}$ in low internal friction angle of subgrade and slope soils $\left(\phi=20^{\circ}\right)$ while it increased $3,87 \mathrm{~m}$ in high internal friction angle of subgrade and slope soils $\left(\phi=40^{\circ}\right)$ with the increase of slope height from $2 \mathrm{~m}$ to $10 \mathrm{~m}$. This effect became more significant when the slope height was greater due to quadratic increase of lateral pressures on the pile with slope height increment.

\section{B. The Effect of Internal Friction Angle of Slope Soils and Subgrade on the Depth of Driven Piles}

Here are 2 sub scenarios i.e.: the pile was designed in subgrade and slope soils with the same and different types of soil as presented in Table 1. This design used $6 \mathrm{~m}$ in slope height. The design analyses were principally performed with the same procedures as utilized in the previous scenario. Results of the analyses were presented in Table $4 \mathrm{a}, 4 \mathrm{~b}$, and $4 \mathrm{c}$ and shown in Figure 6.

Table 4a. The depth of driven piles obtained from variation of the internal friction angle of subgrade with internal friction angle of slope soils $\phi_{\mathrm{f}}=30^{\circ}$ and slope height $\mathrm{H}=6 \mathrm{~m}$

\begin{tabular}{|c|c|c|c|c|c|c|}
\hline$\phi$ & $\mathrm{P}_{\mathrm{a}}$ & $\mathrm{e}$ & $\mathrm{L}(\mathrm{m})$ & $\mathrm{P}_{\mathrm{a}}(\mathrm{e}+\mathrm{L})$ & $0,5 \gamma \mathrm{K}_{\mathrm{p}} \mathrm{BL}^{3}$ & Control \\
\hline $20^{\circ}$ & 106,92 & 2 & 4,85 & 732,40 & 733,10 & Save \\
\hline $30^{\circ}$ & 106,92 & 2 & 4,11 & 653,28 & 656,08 & Save \\
\hline $40^{\circ}$ & 106,92 & 2 & 3,44 & 581,64 & 582,16 & Save \\
\hline
\end{tabular}

Table $4 \mathrm{~b}$. The depth of driven piles obtained from variation of the internal friction angle of slope soils with internal friction angle of subgrade $\phi_{\mathrm{s}}=30^{\circ}$ and slope height $\mathrm{H}=6 \mathrm{~m}$

\begin{tabular}{|l|l|l|l|l|l|l|}
\hline$\phi$ & $\mathrm{P}_{\mathrm{a}}$ & $\mathrm{e}$ & $\mathrm{L}(\mathrm{m})$ & $\mathrm{P}_{\mathrm{a}}(\mathrm{e}+\mathrm{L})$ & $0,5 \gamma \mathrm{K}_{\mathrm{p}} \mathrm{BL}^{3}$ & Control \\
\hline
\end{tabular}

\begin{tabular}{|c|c|c|c|c|c|c|}
\hline $20^{\circ}$ & 158,76 & 2 & 4,87 & 1090,68 & 1091,49 & Save \\
\hline $30^{\circ}$ & 106,92 & 2 & 4,11 & 653,28 & 656,08 & Save \\
\hline $40^{\circ}$ & 71,28 & 2 & 3,46 & 389,19 & 391,44 & Save \\
\hline
\end{tabular}

Table 4c. The depth of driven piles obtained from variation of the internal friction angle of both subgrade and slope soils (subgrade $=$ slope soils) with slope height $\mathrm{H}=6 \mathrm{~m}$

\begin{tabular}{|c|c|c|c|c|c|c|}
\hline$\phi$ & $\mathrm{P}_{\mathrm{a}}$ & $\mathrm{e}$ & $\mathrm{L}(\mathrm{m})$ & $\mathrm{P}_{\mathrm{a}}(\mathrm{e}+\mathrm{L})$ & $0,5 \gamma \mathrm{K}_{\mathrm{p}} \mathrm{BL}^{3}$ & Control \\
\hline $20^{\circ}$ & 158,76 & 2 & 5,77 & 1233,56 & 1234,43 & Save \\
\hline $30^{\circ}$ & 106,92 & 2 & 4,11 & 653,28 & 656,08 & Save \\
\hline $40^{\circ}$ & 71,28 & 2 & 2,91 & 349,98 & 352,41 & Save \\
\hline
\end{tabular}

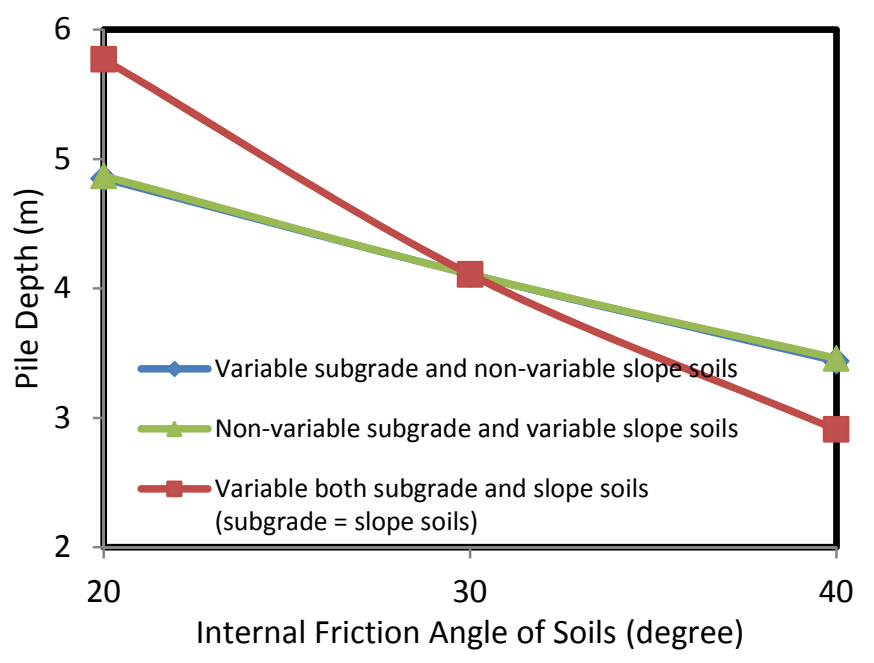

Figure 6. Internal friction angle of soils vs pile depth curves with slope height of $6 \mathrm{~m}$ in subgrade and slope soils with the same and different internal friction angles of soil

The results indicated that the effect of internal friction angle of soils on pile depth was significant when internal friction angle of subgrade was the same as that of slope soils as shown in Figure 6. This is reasonable because both subgrade and slope soils totally have low internal friction angle when the low internal friction angle is applied in this design analysis. On the other hand, low internal friction angle of slope soils was compensated by high internal friction angle of subgrade. The pile depth increased $2,86 \mathrm{~m}$ with the increase of both internal friction angle of subgrade and slope soils simultaneously from $\phi=20^{\circ}$ to $40^{\circ}$. In contrast, it only increased $1,41 \mathrm{~m}$ with the increase in internal friction angle of one of both subgrade and slope soils.

\section{Conclusion}

This study concluded that the effect of slope height on the pile depth was quite significant in granular soils with low 
internal friction angle. The pile depth increased 7,69 $\mathrm{m}$ for the soils with low internal friction angle $\left(\phi=20^{\circ}\right)$ while it increased only $3,87 \mathrm{~m}$ for those with high internal friction angle $\left(\phi=40^{\circ}\right)$ with the increment of slope height from $2 \mathrm{~m}$ to $10 \mathrm{~m}$. Meanwhile the effect of shear strength of soils on the pile depth was more significant in subgrade and slope soils with the same internal friction angle than in those with different internal friction angle. The pile depth increased 2,86 $\mathrm{m}$ in the first type of soils whereas it increased only $1,41 \mathrm{~m}$ in the second one for slope height of $6 \mathrm{~m}$. This study indicated that people should avoid constructing pile foundation to retain very tall slopes in soils with low internal friction angle.

\section{Acknowledgement}

Valuable assistance of Irka Tangke Datu of Ujung Pandang State Polytechnic Lecturer on the structural design analyses are gratefully acknowledged.

\section{References}

[1] B.M. Das, "Principles of Geotechnical Engineering," $3^{\text {rd }}$ ed, Boston: PWS Publishing Company, pp. 316-463, 1994.

[2] B.M. Devi, H.S. Chore, V.A. Sawant,"Analysis of laterally loaded pile groups," IOSR Journal of Civil Engineering, pp. 6064.

[3] D.P. Coduto, "Foundation Design: Principles and Practices," Englewood Cliffs, NJ, USA: Prentice Hall, pp. 514-553, 1994.

[4] F.X. Toha, "Driven Pile Foundation in Tanjung Priok Baru Terminal,"Proc. $10^{\text {th }}$ Indonesian Geotechnical Conference and $19^{\text {th }}$ Annual Scientific Meeting, Jakarta: ISGE, 2015, pp. 45-56.

[5] H.J. Poulus, E.H. Davis, "Pile Foundation Analysis and Design," New York: John Wiley \& Sons, pp. 143-163, 1980.

[6] R.F. Craig, "Soil Mechanics," $6^{\text {th }}$ ed, London: E \& FN Spon, pp. 179-246, 1997.

[7] S. Prakash, H.D. Sharma, "Pile Foundation in Engineering Practice," New York: John Wiley \& Sons, Inc., pp. 322-472, 1990. 